\title{
ANALISIS FAKTOR - FAKTOR YANG MEMPENGARUHI HARGA JUAL KEDELAI TINGKAT PETANI PADA SENTRAL PRODUKSI DI KECAMATAN PEUDADA KABUPATEN BIREUEN
}

(Analysis Factors Affecting The Selling Price Soybean Level Farmer in Central Production in Kecamatan Peudada Kabupaten Bireuen)

\author{
Amirul Fuadi ${ }^{1}$, Elly Susanti ${ }^{1}$, Suyanti Kasimin ${ }^{1 *}$ \\ ${ }^{1}$ Program Studi Agribisnis, Fakultas Pertanian, Universitas Syiah Kuala
}

\begin{abstract}
Abstrak - Harga jual merupakan salah satu faktor yang sangat berpengaruh terhadap petani, salah satunya yaitu tingkat pendapatan yang di peroleh oleh para petani, yang selanjutnya akan berpengaruh terhadap motivasi dan produktivitas kerja dari para petani. Saluran pemasaran yang terlalu panjang, dan kebijakan harga yang tidak memihak pada petani mengakibatkan keuntungan yang di peroleh oleh petani sangat sedikit. Tujuan dari penelitian ini adalah untuk mengetahui faktor- faktor yang mempengaruhi harga jual kedelai tingkat petani di Kecamatan Peudada Kabupaten Bireuen. Berdasarkan hal tersebut, penelitian ini dilakukan untuk mengetahui faktor-faktor apa saja yang berpengaruh terhadap harga jual kedelai tingkat petani. Penelitian ini dilakukan di Kecamatan Peudada Kabupaten Bireuen, Lokasi penelitian dipilih secara sengaja (purposive). Ruang lingkup penelitian ini terbatas pada faktor tingkat produksi, kualitas, penanganan pascapanen dan saluran distribusi pemasaran. Populasi dalam penelitian ini sebanyak 30 orang yang diambil dari tiga desa tersebut yaitu desa Cot Kruet, Pinto Rimba, Ara Bungong. Sedangkan besarnya sampel yang digunakan dalam penelitian ini adalah $15 \%$ dari total populasi penelitian. Model analisis yang digunakan adalah fungsi linier berganda. Hasil analisis koefisiensi determinasi $\left(\mathrm{R}^{2}\right)$ diperoleh nilai sebesar 0,827 yang berarti bahwa tingkat produksi, kualitas, penanganan pascapanen, dan saluran ditribusi pemasaran mempengaruhi harga jual kedelai sebesar 82,7\%, sedangkan sisanya 17,3\% dipengaruhi oleh faktor lain. Hasil analisis secara serempak (uji-f) bahwa tingkat produksi, Kualitas, Penanganan pascapanen, dan saluran distribusi pemasaran berpengaruh nyata terhapap harga jual kedelai tingkat petani di Kecamatan Peudada Kabupaten Bireuen. Analisis secara parsial (uji-t) menyatakan bahwa faktor kualitas dan penanganan pascapanen yang berpengaruh nyata terhadap harga jual kedelai tingkat petani.
\end{abstract}

Kata Kunci: Harga Jual, Tingkat Produksi, Kualitas, Penanganan Pascapanen, Saluran Distribusi Pemasaran

Abstrak - The selling price is one factor that would influence the farmers, one of them is income levels in get the farmers, which later will have an influence to motivation and labor productivity from farmers. Marketing outlets is too long, and policy the price of being impartial the farmers resulting in an advantage in get by farmers very few. The purpose of this study is to find of factors affect the selling price of soybean the farm gate in Kecamatan Peudada Kabupaten bireuen. Based on it, the study is done to find out what factors had an influence on the selling price of soybean farm gate. The study is done in Kecamatan Peudada Kabupaten Bireuen, the research areas was selected deliberately (purposive). Scope this research limited to factors production level, the quality of, post-harvest handling of crops and distribution channels marketing. Population in this study as many as 30 people who is taken from the three the village the village Cot Kruet, Pinto Rimba, Ara Bungong. The amount of sample used in this research was $15 \%$ of the total number of research. Model the analysis used is a function linear multiple. The results of the analysis koefisiensi determination $\left(\mathrm{R}^{2}\right)$ obtained value of 0,827 which means that production level, the quality, post-harvest handling of crops, and channels ditribusi marketing affect the selling price soybean of $82.7 \%$, while the rest $17.3 \%$ influenced by other factors. The results of the analysis in unison ( uji-f ) that production level, the quality, postharvest handling of crops, marketing and distribution channels may had have real impact against the selling price soybean the farm gate in Kecamatan Peudada Kabupaten Bireuen. Analysis in partial ( 
uji-t ) said that factors the quality and post-harvest handling of crops who had have real impact on the selling price soybean the farm gate.

Keywords : The selling price, Production level, The quality, Post-harvest handling of crops, Marketing outlets

\section{PENDAHULUAN}

Kedelai (Glycine $\max (L$.$) Merr) merupakan komoditas pangan yang telah lama$ dibudidayakan di Indonesia, dan salah satu komoditas pangan yang strategis setelah padi dan jagung. Peranan kedelai sebagai komoditas palawija yang kaya akan kandungan protein nabati yang dalam pemanfaatannya memiliki kegunaan yang beragam, terutama sebagai bahan baku industri makanan (tempe, tahu, tauco, susu kedelai, minyak makan dan tepung kedelai) dan bahan baku industri pakan ternak (Sudaryanto dan Swastika, 2007)

Kebutuhan akan kedelai di Indonesia setiap tahun selalu meningkat seiring dengan pertambahan penduduk dan perbaikan pendapatan per kapita. pemenuhan kebutuhan akan kedelai yang merupakan bahan baku utama tempe dan tahu, 67,28\% atau sebanyak 1,96 juta ton harus diimpor dari luar. Hal ini terjadi karena produksi dalam negeri tidak mampu mencukupi permintaan produsen tempe dan tahu. Oleh karena itu, diperlukan suplai kedelai tambahan yang harus diimpor karena produksi dalam negeri belum dapat mencukupi kebutuhan tersebut (Adisarwanto, 2005)

Permasalah kedelai impor akhirnya mendapat sorotan dari kalangan luas, karna dengan adanya impor kedelai lokal kalah bersaing dengan kedelai impor. Oleh karena itu pemerintah mulai menangani masalah tersebut dengan mengatur volume dan waktu penyaluran kedelai dengan tepat, sehingga tingkat harga jual di pasar mulai membaik kembali, bahkan sampai pada tingkat harga yang lebih tinggi dibandingkan dengan masa - masa sebelumnya. Perkembangan tingkat harga jual yang baik akan merangsang petani untuk bergairah kembali di bidang perkedelaian (Suprapto, 2001).

Tabel 1. Perkembangan Harga Produsen dan Harga Konsumen Kedelai di Indonesia, 20102015

\begin{tabular}{rrr}
\hline Tahun & Harga Produsen $(\mathrm{Rp} / \mathrm{kg})$ & Harga Konsumen $(\mathrm{Rp} / \mathrm{kg})$ \\
\hline 2010 & 6.664 & 8.912 \\
2011 & 7.254 & 9.779 \\
2012 & 7.514 & 10.316 \\
2013 & 6.905 & 11.049 \\
2014 & 8.326 & 10.120 \\
\hline
\end{tabular}

Sumber : BPS dan Kemendag 2015

Kabupaten Bireuen merupakan Kabupaten sentral produksi kedelai yang ada di Provinsi Aceh. Selain itu, Kabupaten bireuen juga memiliki prospek pengembangan kedelai, baik produk primer ataupun produk sekunder (olahan) yang telah lama dikembangkan di Kabupaten Bireuen.

Luas tanam luas panen dan produksi yang ada di Kabupaten Bireuen cendrung fluktuatif setiap tahunnya. Produksi di Kabupten Bireuen mengalami peningkatan pada tahun 2013, akan tetapi pada tahun 2014 mengalami penurunan yang sangat signifikan, hal ini disebabkan karena kurangnya minat petani dalam berusaha tani kedelai. Kurangnya minat petani diakibatkan karena harga kedelai yang tidak stabil sehingga petani enggan dalam berusahatani kedelai. Adapun jumlah luas tanam, luas panen dan produksi di Kabupaten Bireuen dari Tahun 2010-2014 tercantum pada Tabel 2 dibawah ini : 
Tabel 2. Luas tanam, Luas panen dan Produksi kedelai dari Tahun 2010-2014 di Kabupaten Bireuen

\begin{tabular}{llrrr}
\hline No & Tahun & Luas tanam $(\mathrm{Ha})$ & Luas panen $(\mathrm{Ha})$ & Produksi (Ton) \\
\hline 1 & 2010 & 23179 & 21264 & 33758 \\
2 & 2011 & 18288 & 15827 & 30141 \\
3 & 2012 & 22657 & 18013 & 30141 \\
4 & 2013 & 24311 & 19834 & 31452 \\
5 & 2014 & 17125 & 12447 & 26438 \\
\hline
\end{tabular}

Sumber : Dinas Pertanian dan Peternakan Kabupaten Bireuen 2015 (diolah)

Turunnya produksi disebabkan oleh turunnya luas tanam kacang kedelai di Kabupaten Bireuen karena harga jual kedelai tingkat petani relatif rendah. Berdasarkan peraturan menteri perdagangan R.I Nomor : 01/M-DAG/PER/I/2015 HDP (Harga Pembelian Kedelai) ditetapkan sebesar Rp. 7.700,-/Kg (tujuh ribu tujuh ratus rupiah per kilogram). Tatapi pada kenyataannya harga beli ditingkat petani tidak sesuai dengan ketetapan pemerintah. Harga tingkat petani hanya hanya berkisar Rp. 3000, - Rp 4000 per kilogram seharusnya harga di tingkat petani bisa lebih tinggi di karenakan karna produksi dalam negeri belum bisa memenuhi permintaan kedelai dalam negeri. Saluran pemasaran kedelai yang terlalu panjang, dan kebijakan harga yang tidak memihak pada petani, mengakibatkan keuntungan yang diperoleh petani sangat sedikit. Ini mengakibatkan kebanyakan petani memilih untuk mengalih fungsikan lahan kedelai mereka ke komoditi tanaman lainnya.

Tujuan penelitian ini untuk mengetahui untuk mengetahui factor apa saja yang mempengaruhi harga jual kedelai tingkat petani pada sentral produksi di Kecamatan peudada Kabupaten Bireuen

\section{METODE PENELITIAN}

Metode yang di gunakan dalam penelitian ini dilakukan dengan metode survey. Pengambilan sampel untuk petani adalah menggunakan Multi Stage Sample. untuk pedagang menggunakan Snowball Sampling. Data primer diperoleh dari dua macam teknik pengumpulan data, yaitu kuisioner dan wawancara. Data sekunder diperoleh dari berbagai instansi atau lembaga terkait seperti BPS serta literatur yang berhubungan dengan penelitian ini. Pupulasi pada penelitian ini adalah petani kedelai yang meliputi Desa Coet Kruet, Desa Pinto Rimba, Desa Ara Bungong. Metode analisis yang digunakan pada penelitian ini adalah metode deskriptif dengan pendekatan kualitatif menggunakan analisis regresi linier berganda

Metode deskriptif dengan pendekatan kualitatif yaitu melakukan penelitian melalui pengamatan dan wawancara untuk memperoleh sebanyak mungkin tentang factor yang mempengaruhi harga jual kedelai.

Menggunakan Regresi linier berganda untuk menguji faktor-faktor yang mempengaruhi harga jual kedelai tingkat petani. Data-data yang telah dikumpulkan disusun dalam bentuk skor. Besarnya skor disesuaikan dengan banyaknya pilihan jawaban rumus sebagai berikut :

$$
Y=a_{0}+a_{1} x_{1}+a_{2} X_{2}+a_{3} x_{3}+a_{4} x_{4}+e
$$

Dimana $\quad \mathrm{Y}=$ Harga kedelai $(\mathrm{Rp} / \mathrm{kg})$

$\mathrm{X} 1=$ Tingkat produksi $(\mathrm{Kg} / \mathrm{ha})$ 
$\mathrm{X} 2$ = Kualitas (Skor)

$\mathrm{X} 3$ = Penanganan pasca panen (Skor)

$\mathrm{X} 4$ = Biaya Distribusi (Rp)

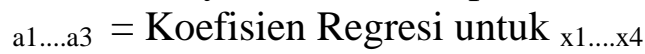

e $\quad=$ Faktor yang tidak terobservasi (error)

Untuk mengetahui besarnya variabel bebas $(\mathrm{X})$ terhadap variabel terikat $(\mathrm{Y})$ secara serempak digunakan uji " $F$ " yaitu :

$$
\boldsymbol{F}=\frac{\text { Jumlah kuadrat }(\mathrm{reg}) / \mathrm{k}}{\text { Jumlah huadrat }(\mathrm{sisa}) \mathrm{n}-\mathrm{k}-1}
$$

Dimana $: \mathrm{n}=$ Jumlah Pengamatan

$\mathrm{k}=$ Jumlah parameter

Level of signifikan $=0,05$

Dengan kaedah keputusan :

Jika $\mathrm{F}_{\text {hit }}>\mathrm{F}_{\text {tabel }}$; maka terima Ha tolak Ho

Jika $\mathrm{F}_{\text {hit }}<\mathrm{F}_{\text {tabel }}$; maka terima Ho tolak Ha

Sedangkan untuk mengetahui pengaruh secara parsial digunakan uji “t”

Dengan rumus : $\mathbf{t}_{\text {hit }}=\frac{a \cdot i}{\text { Sai }}$

Dimana $\mathrm{t}=$ Uji secara parsial

$\mathrm{a}_{\mathrm{i}}=$ Koefesien regresi

$\mathrm{S}=$ Standar deviasi

Level of signifikan $=0,05$

Dengan kaedah keputusan :

Jika $\mathrm{t}_{\text {hit }}>\mathrm{tt}_{\text {abel }}$; maka terima Ha tolak Ho

Jika $\mathrm{t}_{\text {hit }}<\mathrm{t}_{\text {tabel }}$; maka terima Ho tolak Ha

Ha : Artinya Tingkat produksi, kualitas, penanganan pascapanen dan saluran distribusipemasaran berpengaruh nyata terhada harga jual.

Ho : Artinya Tingkat produksi, kualitas, penanganan pascapanen dan saluran distribusi pemasaran tidak berpengaruh nyata terhadap harga jual.

Untuk melihat keeratan hubungan antara variabel bebas dengan variabel terikat dianalisis dengan koefesien determinasi $\left(\mathrm{R}^{2}\right)$, yaitu sebagai berikut :

$$
\mathrm{R}^{2}=\frac{j R(\operatorname{reg})}{J K(\operatorname{Total})}
$$

Dimana $\mathrm{R}^{2}=$ Koefesien determinasi yang menunjukkan kemampuan variasi variabel bebas (tingkat produksi, kualitas, penanganan pascapanen dan saluran distribusi pemasaran). Mampu menjelaskan terhadap variabel terikat (harga kedelai), nilai $\mathrm{R}^{2}$ semakin mendekati 1, maka akan semakin baik. 
$\mathrm{Jk}(\operatorname{Reg}) \quad$ = Jumlah kuadrat-kuadrat untuk regresi

Jk total = Jumlah kuadrat total.

\section{HASIL DAN PEMBAHASAN}

Petani memiliki karakteristik yang beragam, karakteristik tersebut dapat berupa karakter demografis, karakter sosial serta karakter kondisi ekonomi petani itu sendiri. Karakterkarakter tersebut yang membedakan tipe perilaku petani pada situasi tertentu. Berikut adalah karakter demografis dari petani dapat dilihat pada tabel 8 sebagai berikut:

Tabel 3. Karakteristik demografis petani di Kabupaten Bireuen

\begin{tabular}{|c|c|c|c|c|}
\hline No & Uraian & & $\begin{array}{l}\text { Jumlah } \\
\text { (Orang) }\end{array}$ & $\begin{array}{c}\text { Persentase } \\
(\%)\end{array}$ \\
\hline \multirow[t]{2}{*}{1} & \multirow{2}{*}{ Jenis Kelamin } & a. Laki-laki & 24 & 80,00 \\
\hline & & b.perempuan & 6 & 20,00 \\
\hline \multirow[t]{3}{*}{2} & \multirow[t]{3}{*}{ Usia } & a. $0-14$ & - & - \\
\hline & & b. $15-60$ & 28 & 93,33 \\
\hline & & c. $>60$ & 2 & 6,67 \\
\hline \multirow[t]{3}{*}{3} & \multirow[t]{3}{*}{ Pendidikan } & a. 6 & 13 & 46,73 \\
\hline & & b. 9 & 7 & 23,91 \\
\hline & & c. 12 & 12 & 29,34 \\
\hline \multirow[t]{3}{*}{4} & \multirow[t]{3}{*}{ Luas lahan garapan } & a. $<0,5 \mathrm{Ha}$ & - & - \\
\hline & & b. $0,5-2 \mathrm{Ha}$ & 27 & 90,00 \\
\hline & & c. $>2 \mathrm{Ha}$ & 3 & 10,00 \\
\hline \multirow[t]{3}{*}{5} & \multirow[t]{3}{*}{ Pengalaman usaha tani } & a. Rendah $<10$ & 10 & 33,33 \\
\hline & & b. Sedang $10-20$ & 14 & 46,67 \\
\hline & & c. Tinggi > 20 & 6 & 20,00 \\
\hline
\end{tabular}

\section{Jenis Kelamin}

Jenis kelamin menunjukkan tingkat produktivitas seseorang, secara universal tingkat produktivitas laki-laki lebih tinggi dibandingkan produktivitas perempuan. Hal ini sangat dipengaruhi oleh faktor fisik perempuan yang kurang kuat, dalam pekerjaan cenderung menggunakan perasaan atau faktor biologis seperti harus cuti haid atau melahirkan. Adapun data tersebut didapatkan dari lembaran kuesioner yang disebar ke 30 orang petani di 3 desa, data yang di peroleh dari Petani berdasarkan jenis kelamin yaitu responden berjenis kelamin laki-laki 24 orang atau $80 \%$ sedangkan responden perempuan berjumlah 6 orang atau $20 \%$

\section{Umur}

Umur responden merupakan lama responden hidup hingga penelitian dilakukan, umur produktif petani akan mempengaruhi proses adopsi suatu inovasi baru. Menurut BPS (2012), 
berdasarkan komposisi penduduk, umur dikelompokkan menjadi 3 yaitu umur 0-14 tahun dianggap sebagai kelompok penduduk belum produktif, kelompok penduduk umur 15-60 tahun sebagai kelompok produktif dan kelompok umur 60 tahun ke atas sebagai kelompok penduduk yang tidak lagi produktif. Dari hasil penelitian maka didapat distribusi karakteristik umur petani berdasarkan hasil penelitian diketahui berada pada umur produktif 93,33\% petani berada pada kisaran umur > 15-60 Pendidikan

\section{Tingkat pendidikan}

Tingkat pendidikan merupakan jumlah tahun mengikuti pendidikan formal yang ditempuh petani pada bangku sekolah. Pendidikan akan berpengaruh terhadap perilaku dan tingkat adopsi suatu inovasi. Seseorang yang berpendidikan tinggi cenderung lebih terbuka untuk menerima dan mencoba hal-hal yang baru. Berdasarkan hasil penelitian menunjukkan bahwa tingkat pendidikan petani responden tergolong dalam kategori rendah karena 46,73\% berada pada kisaran 0-6 tahun. Saridewi (2010), tingkat pendidikan seseorang dapat mengubah pola pikir, daya penalaran yang lebih baik, sehingga makin lama seseorang mengenyam pendidikan akan semakin rasional.

\section{Luas lahan}

Luas lahan usahatani merupakan keseluruhan luas lahan yang diusahakan petani responden baik milik sendiri, menyewa, maupun menyakap. Fhadoli Hernanto (1990: 64) menggolongkan luas lahan garapan menjadi 3 kelompok yaitu:

1. Lahan garapan sempit yang luasnya kurang dari 0,5 Ha.

2. Lahan garapan sedang yaitu lahan yang luasnya 0,5 sampai dengan $2 \mathrm{Ha}$.

3. Lahan garapan luas yaitu lahan yang luasnya lebih dari $2 \mathrm{Ha}$.

Dari hasil penelitian dapat dilihat bahwa Luas lahan petani berdasarkan hasil penelitian sebanyak 46,66 \% berada pada kisaran luas lahan 0,5-1 Ha tergolong luas tanah petani rendah. Pengalaman Usaha tani

Pengalaman berusahatani memberikan pengaruh yang sangat besar terhadap tingkat keahlian seseorang petani. Dengan pengalaman yang didapat sesorang petani bekerja lebih efisien dan terencana secara matang sehingga dapat meningkatkan produksi yang hasilkan oleh petani.

Dari hasil penelitian dapat dilihat bahwa Pengalaman usahatani petani berdasarkan hasil penelitian 46,67 \% petani memiliki pengalaman lebih dari 10 tahun. Padmowiharjo (1999) pengalaman merupakan pengetahuan yang dialami seseorang dalam kurun waktu yang tidak ditentukan. Pengalaman yang menyenangkan dan memuaskan akan berdampak positif untuk melanjutkan mengadopsi suatu inovasi.

\section{Hubungan Produksi Kedelai, Kualitas kedelai, Penanganan pascapanen, dan Saluran distribusi pemasaran terhadap Harga kedelai tingkat petani di kabupaten bireuen tahun 2016}

Usaha untuk meningkatkan harga jual kedelai tingkat petani merupakan salah satu tujuan guna untuk meningkatkan pendapatan dari petani. Bagitu petani apabila harga jual kedelai mereka tinggi maka pendapatan mereka juga akan tinggi beitu juga sebaliknya. Jika pendapatannya tinggi secara tidak langsung tingkat kesejahteraan petani pun akan semakin baik.

Peningkatan harga jual kedelai tingkat petani itu mempunyai hubungan dengan tingkat Produksi kedelai (X1), Kualitas Kedelai (X2), Penanganan Pasaca Panen (X3) Dan Saluran distribusi (X4). Untuk mengetahui besarnya faktor-faktor yang mempengaruhi harga jual kedelai tingkat petani yaitu menggunakan model regresi linier berganda. Adapun hasil regresi linier berganda bisa di lihat pada tabel berikut ini: 
Tabel 4. Hubungan Antara Variabel Dependen dan Variabel Independent

$\mathrm{R}^{2}: 0,827$

F Tabel : 1,76

T Tabel : 1,70814

\begin{tabular}{llrrrr}
\hline Variable & Nama Variabel & Koefisien & Std. Error & \multicolumn{1}{l}{ Sig } & \\
Ao & (constant) & 1812.800 & 373.090 & 4.859 & .000 \\
$\mathrm{X}_{1}$ & Tingkat Produksi & -.178 & .272 & -.655 & .518 \\
$\mathrm{X}_{2}$ & Kualitas & 102.086 & 30.439 & 3.354 & .002 \\
$\mathrm{X}_{3}$ & Penanganan & 94.521 & 51.553 & 1.833 & .004 \\
& Pascapanen & & & & .703 \\
$\mathrm{X}_{4}$ & Distribusi & 31.852 & 82.468 & .386 & \\
& Pemasaran & & & & \\
\hline
\end{tabular}

Sumber: Data primer (diolah 2016) berikut :

Dari table perhitungan statistic di atas maka didapat persamaan regristasi sebagai

$$
Y=1812,800-0,178 X_{1}+102,086 X_{2}+94,521 X_{3}+31,852 X_{4}
$$

Berdasarkan koefisien regristasi dari masing-masing variable bebas pada persamaan regristasi di atas, maka dapat dijelaskan pengertian sebagai berikut :

a. Jika nilai $X_{1}, X_{2}, X_{3, \text { dan }} X_{4}$, dianggap 0 atau konstan, maka akan meningkatkan Harga jual kedelai sebesar Rp. 1812,800/Kg

b. $\mathrm{X}_{1}$ : nilai koefisien $-0,178$ menunjukkan bahwa setiap peningkatan produksi $1 \mathrm{~kg}$ produksi, maka akan menurunkan harga jual kedelai sebesar Rp.0,178/kg

c. $\mathrm{X}_{2}$ : nilai koefisien 102.086 menunjukkan bahwa setiap peningkatan 1 satuan tingkatan kualitas kedelai baik dari segi warna, ukuran biji, kadar air, keseragaman biji, ataupun persentase kotoran maka akan meningkatkan harga jual kedelai sebesar Rp. $102,086 / \mathrm{kg}$.

d. $\quad \mathrm{X}_{3}$ : nilai koefisien 94,521 menunjukkan bahwa setiap peningkatan 1 satuan tingkatan penanganan pascapanen kedelai baik dari segi penetuan waktu panen, teknik pemanenan, cara peneringan brangkasan, sistem perontokan, ataupun cara pengeringan biji maka akan meningkatkan harga jual kedelai yaitu sebesar Rp. 94,521/kg.

e. $\mathrm{X}_{4}$ : nilai koefisien 31,852 menunjukkan bahwa setiap perubahan saluran distribusi pemasaran, dari produsen ke konsumen, produsen ke pedangang pengumpul, atau produsen ke pedagang besar maka akan meningkatkan harga jual kedelai sebesar Rp. $31,852 / \mathrm{kg}$.

\section{Uji Serempak (F)}

Secara serempak hasil analisa korelasi diperoleh koefisien determinasi $\left(\mathrm{R}^{2}\right)$ sebesar 0,827 yang berarti bahwa 82,7 persen variasi perubahan harga jual kedelai secara bersamasama dipengaruhi oleh variabel produksi, kualitas, penanganan pascapanen dan saluran distribusi pemasaran. Sedangkan sisanya 17,3 persen dipengaruhi oleh faktor-faktor lain diluar faktor-faktor didalam penelitian ini. Hal ini menunjukkan hubungan yang erat antara harga jual kedelai dengan faktor produksi, kualitas, penanganan pascapanen, dan saluran distribusi pemasaran pada sentral produksi kedelai di Kabupaten Bireuen.

Hasil uji serempak menggunakan uji " $F$ " fungsi linier berganda diperoleh $F_{\text {hitung }}=$ 29,930 sedangkan $F_{\text {tabel }}=1,76$ sehingga dapat disimpulkan bahwa $F_{\text {hitung }}>F_{\text {tabel }}$. Hal ini 
menunjukkan bahwa produksi, kualitas, penanganan pasca panen, berpengaruh nyata terhadap harga jual kedelai dapat diterima (terima $\mathrm{H}_{\mathrm{a}}$ tolak $\mathrm{H}_{0}$ ).

\section{Uji parsial ( $\mathbf{T}$ )}

Untuk melihat secara statistic tingkat signifikan koefisien regresi (pengaruh dari masing-masing variable dependent), maka diuji secara terpisah (parasial) antara variable independent terhadap variable dependent dengan uji-t. hasil pengujian secara parsial atau uji-t bagi setiap variable dengan tingkat kepercayaan 95\% (taraf nyata $=5 \%$ ) adalah sebagai berikut:

\section{Tingkat produksi}

Hasil analisis terhadap variable Tingkat produksi diperoleh $t_{\text {hitung }}=-0,178$ sedangkan $\mathrm{t}_{\text {tabel }}=1,70814$, hal ini menunjukkan $\mathrm{t}_{\text {hitung }}<\mathrm{t}_{\text {tabel }}$. Dari hasil perhitungan ini menunjukkan bahwa variable Produksi tidak berpengaruh nyata terhadap harga jual kedelai, karena semakin banyak hasil produksi yang di hasilkan oleh petani maka akan semakin menurun harga jual kedelai. Hal ini sesuai dengan hukum permintaan (law of demand) dimana disebutkan bahwa semakin turun tingkat harga, maka semakin banyak jumlah barang yang tersedia dan sebaliknya semakin naik tingkat harga semakin sedikit barang yang tersedia.

\section{Kualitas}

Dari hasil analisis terhadap variabel kualitas diperoleh $t_{\text {hitung }}=3,354$ sedangkan $t_{\text {tabel }}=$ 1,70814 , hal ini menunjukkan $t_{\text {hitung }}>t_{\text {tabel }}$. Dari hasil perhitungan ini menunjukkan bahwa variable kualitas kedelai yang di hasilkan petani berpengaruh nyata terhadap harga jual kedelai tingkat petani. Kotler dan Amstrong (2008), menyebutkan kualitas produk ( product quality ) adalah salah satu sarana positioning utama dari pemasaran. Kualitas mempunyai dampak pada kinerja produk dan jasa; oleh karena itu kualitas berhubungan erat dengan nilai dan kepuasan pelanggan.

\section{Penangan pascapanen}

Dari hasil analisis terhadap variabel penanganan pascapanen diperoleh $t_{\text {hitung }}=1,833$ sedangkan $t_{\text {tabel }}=1,70814$, hal ini menunjukkan bahwa $t_{\text {hitung }}>t_{\text {tabel }}$. Dari hasil perhitungan ini menunjukkan bahwa variable penanganan pascapenen berpengaruh nyata terhadap harga jual kedelai tingkat petani. Penanganan pasca panen yang tepat berpengaruh terhadap tingkat kehilangan hasil pasca panen. Kehilangan paling nyata adalah kuantitas seperti penurunan bobot dan hilangnya produk, baik sebagian ataupuan seluruhnya yang disebabkan oleh kerusakan atau hilang. Bentuk kehilangan hasil yang sedikit terlihat adalah menurunnya kualitas, seperti kerusakan fisik, kehilangan daya tumbuh, dan penurunan nilai jual yang disebabkan oleh turunnya harga. (BPP SDM Pertanian, 2015)

Hal ini menunjukkan bahwa apabila penanangana pasca panen dari mulai pemanenan sampai dengan pengeringan bijinya bagus maka akan mempengaruhi harga jual kedelai. Jika biji kedelai yang di jual kepada pedagang cukup bagus kering, dan kilatanya pun bagus yang ditawarkan ke pedagang cukup memuaskan maka pedagang akan memberikan harga yang cukup bagus pula. Apabila harga yang di tawarkan untuk petani bagus maka akan meningkatkan semangat petani dalam berusahatani kedelai.

\section{Saluran distribusi pemasaran}

Dari hasil analisis terhadap variabel Saluran distribusi pemasaran diperoleh $t_{\text {hitung }}=$ 0,386 sedangkan $t_{\text {tabel }}=1,70814$, hal ini menunjukkan bahwa $t_{\text {hitung }}<t_{\text {tabel }}$. Dari hasil perhitungan ini menunjukkan bahwa variabel saluran distribusi pemasaran tidak berpengaruh nyata terhadap harga jual kedelai, hal ini dikarenakan semakin jauh saluran distribusi kedelai perbedaan harganya tidak terlalu signifikan di karenakan harga yang di tawarkan pedagang pengumpul tidak terlalu berbeda jauh dengan harga yang di tawarkan pedangang besar. 
Sehingga dapat disimpulkan saluran distribusi pemasaran tidak berpengaruh secara signifikan terhadap harga jual kedelai tingkat petani.

\section{KESIMPULAN DAN SARAN}

Dari hasil dan pembahasan di atas dapat disimpulkan bahwa faktor yang berpengaruh nyata terhadap harga kedelai di kecamatan Peudada yaitu faktor Tingkat produksi, kualitas, penanganan pascapanen, dan saluran distribusi pemasaran.

Secara parsial faktor kualitas kedelai dan penanganan pascapanen berpengaruh nyata terhadap harga jual kedelai, hal ini dapat di lihat dari perhitungan $t_{\text {hitung }}>t_{\text {tabel }}$ dengan taraf kepercayaan 95\% dan tingkat kesalahan yang ditoleran adalah $\alpha=0,05$.Tingkat produksi dan saluran distribusi pemasaran tidak berpengaruh nyata terhadap harga jual kedelai tingkat petani pada sentral produksi kedelai di kubpaten bireuen, hal ini dapat di lihat dari hasil perhitungan $t_{\text {hitung }}<t_{\text {tabel }}$ dengan taraf kepercayaan $95 \%$ dan tingkat kesalahan yang di toleran adalah $\alpha=0,05$.

\section{DAFTAR PUSTAKA}

Adisarwanto, T. 2005. Kedelai. Penebar Swadaya, Jakarta.

Hernanto,F.1993. Ilmu Usahatani. Penebar Swadaya. Jakarta

Kotler, Philip; Armstrong, Garry, 2008. Prinsip-prinsip Pemasaran, Jilid 1, Erlangga, Jakarta.

Padmowihardjo,S. 1999. Psikologi Belajar Mengajar. Universitas Terbuka. Jakarta

Peraturan menteri perdagangan nasional. No 1 tahun 2015. Penetapan Harga Pembelian

Kedelai Petani Dalam Rangka Pengamanan Harga Kedelai Di Tingkat Petani. Permendag. Jakarta.

Sudaryanto T. dan Swastika, D.K.S. 2007. Ekonomi Kedelai di Indonesia. Dalam Kedelai Tehnik Produksi dan Pengembangan. Badan Penelitian dan Pengembangan Pertanian. Pusat Penelitian dan Pengembangan Tanaman Pangan. Bogor.

Sudjana. 2002. Metode Statistika. Torsito. Bandung 